\title{
Postpartum Psychiatric Disorders: Review of the Research History, Classification, Epidemiological Data, Etiological Factors and Clinical Presentations
}

\author{
Jelena Stojanov ${ }^{1}$, Miodrag Stanković2,3, Olivera Žikić ${ }^{2,3}$, Jovana Antonijević ${ }^{2}$ \\ ${ }^{1}$ Special Hospital for Psychiatric Diseases "Gornja Toponica“, Niš, Serbia \\ ${ }^{2}$ University of Niš, Faculty of Medicine, Niš, Serbia \\ ${ }^{3}$ Centre for Mental Health Protection, Clinical Centre Niš, Niš,Serbia
}

\section{SUMMARY}

Postpartum psychiatric disorders are mental disorders which occur after childbirth. Untreated depression and anxiety during pregnancy as well as stress and previous episodes of depression are significant risk factors for postpartum psychiatric disorders. Postpartum blues, postpartum depression and postpartum psychosis, as well as postpartum anxiety disorders, are most commonly reported after delivery. The occurrence of postpartum depression increases the likelihood of psychiatric morbidity later in life. The presence of psychotic symptomatology with psychomotor agitation and unpredictable behavior is a significant risk factor for suicide or infanticide. Studies have shown that more than half of women with depression during pregnancy or postpartum have some comorbid anxiety disorder. The possibility of developing a panic disorder and obsessive-compulsive disorder increases after delivery, while the prevalence of generalized anxiety disorder is reduced during that period of time. A reliable instrument for screening the spectrum of postpartum mental disorders is the Edinburgh Postnatal Depression Scale - EPDS. Postpartum psychiatric disorders disturb the central psychological process, i.e. the development of emotional relationship between mother and child, and negatively affects on the behavior, cognitive development and physical health of the child.

Key words: delivery, postpartum, depression, psychosis, anxiety disorders

Corresponding author:

Jelena Stojanov

E-mail: jelena.a.86.ja@gmail.com 


\section{INTRODUCTION}

Postpartum psychiatric disorders are mental disorders which occur in vulnerable women after childbirth (1). They are accompanied by a clinically significantly change in the perception of themselves and others, subjective experience of inadequacy and incompetence, general non-functionality, and they cause problems in marriage, affect parenting and have a severe effect on the behavior, cognitive development and physical health of the child (2).

\section{History}

The history of research and description of postpartum psychiatric disorders has led to several definitions. Terms such as "lactation madness" or "milk fever" are associated with Hippocrates (IV century BC) who explained postpartum mental disorders by retention of milk and its direct flow into the blood, while in the 19th century Jean-Étienne Dominique Esquirol regarded "madness that occurs after birth" to be associated with lactation failure. Blandford, who did not deny Esquirol's claims, considered the negative effects of breast-feeding, such as anemia, fatigue and exhaustion, to be precipitating factors, especially if breast-feeding was extended for up to twelve months (3). Holmes' assumption (1847), which had stated that postpartum "mental disturbances" emerged as a result of postpartum infections, was later proved (4). Some authors have rejected the significant association of psychiatric disorders with delivery (5). During the first half of the twentieth century, postpartum mental disorders were included in the existing categories of mental disorders, primarily of neurochemical and hormonal nature (6).

The term "postpartum" stands for a period which starts at the fourth stage of labor and lasts for 4-6 weeks, and it is as such included in the nomenclature of the fourth revision of the Diagnostic and Statistical Manual of Mental Disorders (DSM-IV) (7). In 2004, Brockington gave a separate and more comprehensive classification of postpartum psychiatric disorders, which included: postpartum blues, postpartum depression, postpartum psychosis and postpartum anxiety disorders (8).

The fifth revision of the Diagnostic and Statistical Manual of Mental Disorders (DSM-V) defines postpartum depression as a non-specific depressive disorder with onset within the first four weeks of postpartum in patients with no previous history of major depression, unless the criteria for a major depressive episode are met. Furthermore, postpartum psychosis is defined as a short-term psychotic disorder with the postpartum onset, if the disorder occurs during pregnancy or within four weeks postpartum (9). Nevertheless, postpartum depression may occur after more than four weeks postpartum and also requires treatment, which leaves room for future correction of classification criteria. Postpartum mood-related episodes may be accompanied by anxiety and even with panic attacks, and these episodes can be with or without psychotic symptoms. Psychotic symptomatology, in which hallucinations or delusions dominate, often leads to infanticide (2). According to DSM-V, severe postpartum depressive or manic episodes with psychotic symptomatology occur with a frequency ranging from 1 in 500 to 1 in 1000 deliveries, and is more common in primiparas, as well as in women with an earlier history of depressive or bipolar disorder, or family history of bipolar disorder. The risk of recurrence after each subsequent delivery in women who already had a postpartum psychotic episode is up to $50 \%$ (9).

The International Classification of Diseases (ICD11) includes the postpartum spectrum of affective mental disorders in the period of up to six weeks after the delivery in the form of depressive episodes with or without psychotic symptomatology (10).

Symptoms that normally occur in the postpartum period, including tiredness, rapid fatigue and increased irritability, as well as sleep and nutritional disorders, further complicate the process of classification. Cultural factors can significantly contribute to the postponement of professional assessment, especially in environments with a prevailing stereotype that the postpartum period is the time of greatest happiness for women (11).

\section{Postpartum blues, "Third Day Syndrome"}

Postpartum sadness or blues is a frequently occurring condition with a prevalence of up to $85 \%$ occurring from the third day ("Third Day Syndrome") until the end of the first month after the delivery (12). It is described as a normal physiological response to changes in hormonal status after the childbirth, during the period in which an emotional attachment to the child is formed. It is accompanied by a subjective lack of energy, weakness, sensitivity, sudden changes in mood, dysphoria, tearfulness, confusion, generalized anxiety and sleep and nutritional disorders.

Postpartum blues is most often seen as an endogenous condition, even though stress, depression during pregnancy and previous depressive episodes are not disregarded as contributing factors (12). Although the etiology is unclear, research suggest the importance of sud- 
den decrease in estrogen and progesterone levels, as well as the mother's personality structure (13). It is associated with a sudden drop in neuroactive substance with GABA agonist influence (GABAAR $\delta$ and $\gamma 2$ subunits), which is formed during pregnancy (13).

\section{Postpartum depression}

Postpartum depression was previously defined as depression occurring after delivery. The latest data suggests that it often occurs during pregnancy and can last for several months and even up to a year (14).

\section{Epidemiology}

The exact prevalence of postpartum depression is uncertain. Most of the available literature cites the prevalence of $10-15 \%$, and even up to $25 \%$ (15). Prevalence in mothers of full-term babies born in Germany is approximately 19\% (16) and in Japan 10-19\% (17). In adolescents aged 14 to 18 years, the prevalence is estimated at $26 \%$ (18). Compared to mothers of full-term babies, mothers of prematurely born babies are at a higher risk of postpartum depression with a prevalence of up to $40 \%$ (15). In mothers of babies with low birth weight, the prevalence varies between $8.5 \%$ and $33 \%$ (15). Assessing the frequency of postpartum depressive disorders, the research conducted in Serbia found elevated scores for depression in $11.8 \%$ of respondents in the postpartum period (19). A literature review suggests that $20 \%$ of women with postpartum depression will suffer from depression even one year after the delivery, and 13\% even after two years (20). Suicide is a common cause of death in high-income countries during the first year after the delivery (21), with an incidence of as much as $20 \%$ of all post-partum deaths and is considered to be the second cause of mortality in postpartum women (22).

\section{Etiology}

Despite the multifactorial etiology, a specific risk factor for postpartum depression remains unknown. Pregnancy is a stressful period that can be accompanied by additional stressful circumstances, ranging from life in poverty with a constant lack of resources, unhealthy living conditions and lack of safety, to raising a larger number of children, single motherhood or stress specifically associated with pregnancy, including fears of pregnancy and childbirth, motherhood and worries for the health of the child.
The most frequently described risk factors are: previous psychiatric disorders, history of mood and anxiety disorders, and particularly untreated depression and anxiety during pregnancy (23).

A significant contributing factor is hormonal disbalance. Changes in levels of reproductive hormones estradiol and progesterone immediately before and after the delivery are associated with depressive mood and anxiety (24). The association of thyroid disorders with symptoms of anxiety and mood disorders in the postpartum period (25) is described. Prolactin levels are associated with anxiety, depression and hostility, both in pregnant women and women who are not pregnant. In mothers who breastfeed, prolactin levels remain elevated for several months. Studies have shown that postpartum depression is more common in women who do not breastfeed (26). The role of oxytocin in birth and lactation is already known (25). One study found that oxytocin levels were inversely proportionally associated with the symptoms of depression in the third trimester and eight weeks postpartum; these levels also affect breastfeeding (27). Oxytocin could play a role in the initiation and manifestation of the mother's protective behavior (28). A lower level of oxytocin in pregnancy is a risk factor for postpartum depression. Mothers without mood disorders have higher concentrations of oxytocin (29).

A more pronounced increase in cortisol levels in late pregnancy and a sudden decline in these levels during the delivery is associated with low birth weight, premature birth, childhood health problems and postpartum depression in mothers (30). The correlation between depression in the first trimester of pregnancy and high risk of premature delivery, low birth weight of the child, as well as with sleep disturbances as an additional stressor were observed (31).

Inadequate nutritional intake may lead to premature birth, low birth weight, and delayed psychomotor development in children. Reduced vitamin D levels in pregnancy are associated with preeclampsia, caesarian delivery and postpartum depression (32).

Risk factors with a lower degree of association with postpartum depression, which are observed in developing countries, are: type of the delivery, parity and sex of the child, lower level of mother's education, low income and unemployment, unplanned or unwanted pregnancy, poor quality of life and stressful life events (33).

Contributing factors taken into account are marital problems and current or previous intimate partner violence (11). Anxiety is associated with several com- 
plications during pregnancy and the outcome of pregnancy. Most women successfully cope with it and are able to control their fears, while some of them suffer from extreme anxiety during pregnancy and in postpartum period. A surgical procedure may also be a consequence of anxiety (caesarian delivery without a valid medical reason), in order to avoid experiencing a vaginal delivery due to fear of childbirth. Predictive factors also include: younger age, single parenthood, mothers with older children, low self-esteem, postpartum blues, and unemployment (34). Women in a psycho-socially unfavorable position, who are socially isolated, are at a higher risk of postpartum depression (34).

\section{Depression assessment tool (Edinburgh Postnatal Depression Scale - EPDS)}

The Edinburgh Postnatal Depression Scale (EPDS) is widely used nowadays. It consists of ten self-reported items, with the aim of screening for postpartum depression. It is recommended to be used in the period from the second week to the third month postpartum. The scale identifies only the risk of postpartum depression and must be followed by a more detailed diagnostic assessment. It is widely available, easily implemented and well-received by patients. It can be used both in women in postpartum and in women with slightly older children, as well as in pregnant women (35). The scale has been translated and standardized in Serbia (36). The scale also measures anxiety and can be a general tool for screening the entire spectrum of postpartum psychiatric disorders.

\section{Postpartum psychotic mood disorders}

Postpartum psychotic mood disorder is the most serious and rarest occurring form of postpartum disorders with a prevalence of 0.1 to $0.2 \%$ (37). The prevalence is as high as $1-2 \%$ if there is a history of previous episodes of affective disorders accompanied by a positive family history in first and second-degree relatives (6). Psychotic disorders occurring in postpartum pose a high risk of in-fanticide (10). Significant risk factors include younger age, first pregnancy, low level of education and rural place of origin (38). Postpartum psychosis is considered to be an endogenous disorder (39). It is considered by some to be a variant of bipolar affective disorder (40), while it is seen by others as an organic psychosis manifested as organic delirium or psychogenic condition, which takes on a form of mania, depression or acute psychosis (41).
A complete loss of sleep, accompanied by bizarre, depressive, nihilistic or paranoid delusions about the patient and her child, hallucinations of all senses, psychomotor agitation and unpredictable behavior, dominates in the clinical presentation. If the episode is manic, unstoppable verbal production, accompanied by psychomotor agitation and delusions of grandeur, special abilities, persecution and influence, is clinically observed. In case of a schizophrenic disorder, loss of emotional resonance both towards the child and the partner, asociality, incomprehensible and unusual speech and bizarre behavior dominate in the clinical presentation.

In confused-delirious forms, the patient is disoriented, irritable, incoherent, with possible visual hallucinations. In this form, organic etiology should be excluded.

Symptoms require treatment in hospital conditions, taking into account the risk for the child or of selfinjury, which is often the case (37). Significant risk factors for suicide or infanticide are: older age of the mother, better socio-economic status and previous history of mental disorders (37).

\section{Postpartum anxiety disorders}

Anxiety disorders are often overlooked, although most of them occur in the early twenties, at a time when most women become pregnant. The prevalence of postpartum anxiety disorders is as high as $20 \%$, making them as frequentor even more frequent than mood disorders (42). The basic symptoms that accompany anxiety disorders are: a sense of fear, sense of potential danger and endangerment, as well as avoiding any situations that cause fear. During pregnancy, fear is associated with the childbirth, and after giving birth with the experience of loss of control, lack of trust in medical staff, and the fear for one's own and the life of one's child.

Studies have shown that more than half of women with postpartum depression comorbidly have some type of anxiety disorder (43). Fear from the birth of a child is called tokophobia; it has an onset either in the childhood or after the woman finds out she is pregnant, and it appears in comorbidity with postpartum depression (44). It was shown that the younger age and higher level of education correlated with the higher incidence of the symptoms of anxiety disorders (43). Sleep disorders, particularly insomnia, may aggravate anxiety, especially when insomnia is accompanied by obsessive thoughts in the absence of depressive symptomatology. It has been shown that factors contributing to anxiety are the ces- 
sation of breast-feeding and lower levels of oxytocin (43)

It is known that panic attacks stop during pregnancy due to anxiolytic effect of progesterone, decreased sympathetic activity and decreased cortical alertness. After childbirth, the possibility of occurrence of panic attacks is increased, in the form of an overwhelming fear of death, madness and loss of control over one's own behavior. If a disabling fear of recurring panic attack emerges in between panic attacks, the diagnosis of a panic disorder is given. Studies have shown that women who have been subjected to violence anytime during the year before the delivery are more susceptible to a panic disorder in the postpartum period (45).

Research indicate a reduction in the prevalence of generalized anxiety disorder (GAD) during the postpartum period (46). It is thought that obsessive-compulsive disorder (OCD) is present before conception and that pregnancy only intensifies its symptomatology. A meta-analysis has shown that there is a greater risk of the occurrence of OCD during the postpartum period than during any other period in the woman's life-time (47). Obsessions are mostly related to the act of hurting the child, followed by intense fear and compulsive avoidance of the child. Several studies indicate that GAD and OCD occurring in comorbidity are more frequent during the postpartum period (48). OCD and other anxiety disorders often occur in women who have had problems with their diet before pregnancy, and who find it difficult to adhere to an adequate diet regime during the postpartum.

Post-traumatic stress disorder (PTSD) occurs in the postpartum period and is mostly caused by a traumatic event prior to conception, during pregnancy or during the delivery. It occurs in comorbidity with depression and postpartum anxiety disorders, and is associated with obesity, premature delivery due to complications and high intensity stress (49).

\section{The course and prognosis of postpartum psychiatric disorders}

Most women with postpartum mental disorders will experience a unipolar major depressive episode during their lifetime, and the risk of recurrent episode exists in each subsequent pregnancy. The prognosis of postpartum depression is favorable, but there is a risk of suicide and infanticide, and an increased likelihood of psychiatric morbidity later in life (50). Severe depressive episodes and suicide attempts during pregnancy are associated with mental retardation and congenital anomalies in children (50). Postpartum bleeding symptoms spontaneously go away in two weeks, and although they do not inflict permanent damage, they are risk factors for postpartum depression and other anxiety disorders (especially if they last longer than two weeks) and may be an indicator of a preexisting anxiety disorder. The first postpartum psychotic episode increases the risk of developing bipolar affective disorder, while women with the preexisting diagnosis of bipolar affective disorder have an increased risk for depression, mania and psychosis during the peripartum period (51). Although in most cases a complete remission is achieved, in $40 \%$ of the cases the disorder is recurrent in each subsequent pregnancy, and occurs even more often when a woman is not pregnant (37).

Anxiety and depression present after the delivery are associated with gestational diabetes, obesity, preeclampsia, and increased risk of cardiometabolic diseases later in life (52). Lactation failure and shortened lactation time in women with postpartum mental disorders increase the risk of breast and ovarian cancer (53).

Women with postpartum mental disorders find it difficult to establish an emotional connection with their children. They find it difficult to independently care for their children, and more often than not they endanger them. Children often remain unvaccinated and do not develop adequate eating habits. They suffer from cardiovascular complications and gastrointestinal and lower respiratory tract infections more frequently. Children born in mothers who suffer from postpartum depression are more likely to have attachment problems (54). They are often withdrawn and isolated from their peer group, adopting the observed form of their mothers' behavior. They have a difficulty developing an interactive dialogue, they develop slower than others and are uninterested and negative towards the mother, exhibiting an uncertain form of attachment during separation (54). It is more difficult for them to learn to recognize and express emotions and are at a greater risk of having similar disorders while growing up (55).

\section{CONCLUSION}

Postpartum is the period in which exacerbations of already existing mental disorders are more frequent, as well as the period in which mental disorders occur in women who previously had no such disorders. When not recognized on time, postpartum psychiatric disorders impact the psychological, physical and social condition of the entire family. Much needed prevention of these disorders is made difficult by the belief that low mood after the delivery is common and clinically in- 
significant, as well as by the increased focus on physical health of the mother and child during the discharge from the hospital, while neglecting the mother's mental state. Early identification and treatment of postpartum depression and other postpartum psychiatric disorders can significantly reduce the rate of family morbidity and mortality, and significantly affect the central psychological process in the postpartum period, related to the development of the emotional relationship between the mother and child. 


\section{References}

1. Zisook S, Burt V. Psychiatric Disorders During Pregnancy. Psychiatric Times 2003;10(1).

2. O'Hara MW, McCabe JE. Postpartum depression: current status and future directions. Annu Rev Clin Psychol 2013; 9, 379-407.

https://doi.org/10.1146/annurev-clinpsy-050212185612

3. Blandford GF. Insanity and its treatment:lectures on the treatment, medical and legal, of insane patients. William Wood \& Co, New York 1886; 3ed: 56-7.

4. Hamilton JA, Sichel DA. Prophylactic measures in Postpartum Psichiatric Illness: A Picture Puzzle, (ed.) Hamilton JA. Harberger PN. Philadephia PA. University of Pennsylvania Press 1992; pp 219-54. https://doi.org/10.9783/9781512802085

5. Boyd DA. Mental disorders associated with childbearing. Am J Obstet Gynecol 1992; 43:148-165, 33548.

6. Ali Burham Mustafa. A historical perspective of perspective of postpartum depression: Suffering in Silence. JSZMC 2016; 7(2):936.

7. American Psychiatric Association. Diagnostic and Statistical Manual of Mental Disorders, 4th Edition, American Psychiatric Association, Washington DC 1994;375-87.

8. Brockington I. Postpartum psychiatric disorders. Lancet 2004;363(9405):303-10. https://doi.org/10.1016/S0140-6736(03)15390-1

9. American Psychiatric Association. Diagnostic and Statistical Manual of Mental Disorders, Fifth Edition. Diagnostic and Statistical Manual of Mental Disorders, Fifth Edition. Arlington, VA: American Psychiatric Press, Inc; 2013; 271-80.

https://doi.org/10.1176/appi.books.9780890425596

10. WHO. International Statistical Classification of Diseases and Related Health Problems, 11 $1^{\text {th }}$ Revision: ICD-11. World Health Organization, Geneva, June 2018.

https://doi.org/10.1071/SH17086
11. Norhayati MN, Hazlina NH, Asrenee AR et al. Magnitude and risk factors for postpartum symptoms: a literature review. J Affect Disord 2015; 1;175: 34-52. https://doi.org/10.1016/j.jad.2014.12.041

12. Evans J, Heron J, Francomb H et al. Cohort study of depressed mood during pregnancy and after childbirth. BMJ 2001; 323:257-60.

https://doi.org/10.1136/bmj.323.7307.257

13. Pirec V. Postporođajni emocionalni poremećaji. Seminar Instituta za mentalno zdravlje, Beograd, 2003.

14. Donna E. Stewart. Postpartum Depression. N Engl J Med 2016; 1;375:2177-86. https://doi.org/10.1056/NEJMcp1607649

15. Vigod SN, Villegas L, Dennis CL et al. Prevalence and risk factors for postpartum depression among women with preterm and low-birth-weight infants: a systematic review. BJOG 2010; 117,540-50. https://doi.org/10.1111/j.1471-0528.2009.02493.x

16. Hubner-Liebermann B, Hausner $H$, Wittmann M. Recognizing and treating peripartum depression. Dtsch Arztebl Int 2012;109:419-24. https://doi.org/10.3238/arztebl.2012.0419

17. Yamashita H, Yoshida K, Nakano H et al. Postnatal depression in Japanese women. Detecting the early onset of postnatal depression by closely monitoring the postpartum mood. J Affect Disord 2000; 58: 14554.

https:/doi.org/10.1016/S0165-0327(99)00108-1

18. Troutman BR, Cutrona CE. Nonpsychotic postpartum depression among adolescent mothers. J Abnorm Psycho 1990; 99, 69-78.

https://doi.org/10.1037//0021-843X.99.1.69

19. BK Dmitrovic, MG Dugalić, GN Balkoski, A Dmitrovic, I Soldatovic. Frequency of perinatal depression in Serbia and associated risk factors. Int J Soc Psychiatry 2013; Vol 60, Issue 6, pp. 528-32. https://doi.org/10.1177/0020764013511067 
20. Goodman JH. Postpartum depression beyond the early postpartum period. J Obstet Gynecol Neonatal Nurs 2004; 33: 410-20. https://doi.org/10.1177/0884217504266915

21. Esscher A, Essen B, Innala E, Papadopoulos FC, Skalkidou A, Sundstrom-Poromaa I et al. Suicides during pregnancy and 1 year postpartum in Sweden, 1980-2007. Br J Psychiatry 2016; 208, 462-9. https://doi.org/10.1192/bjp.bp.114.161711

22. Lindahl V, Pearson J, Colpe L. Prevalence of suicidality during pregnancy and the postpartum. Arch Womens Ment Health 2005; 8, 77-87. https://doi.org/10.1007/s00737-005-0080-1

23. Wisner KL, Sit DKY, McShea MC. Onset timing, thoughts of self-harm, and diagnoses in postpartum women with screen-positive depression findings. JAMA Psychiatry 2013; 70: 490-8.

https://doi.org/10.1001/jamapsychiatry.2013.87

24. Bloch M, Schmidt PJ, Danaceau $M$ et al. Effects of gonadal steroids in women with a history of postpartum depression. Am J Psychiatry 2000; 157: 92430.

https://doi.org/10.1176/appi.ajp.157.6.924

25. Stuebe AM. Failed lactation and perinatal depression: common problems with shared neuroendocrine mechanisms? J Womens Health (Larchmt) 2012; 21:264-72.

https://doi.org/10.1089/jwh.2011.3083

26. Cláudia CastroDias, Bárbara Figueiredo. Breastfeeding and depression: A systematic review of the literature. J Affect Disord 2015; 171:142-54. https://doi.org/10.1016/j.jad.2014.09.022

27. Stuebe AM, Grewen K, Meltzer-Brody S. Association between maternal mood and oxytocin response to breastfeeding. J Womens Health (Larchmt) 2013; 22:352-61. https://doi.org/10.1089/jwh.2012.3768

28. Neumann ID, Landgraf R. Balance of brain oxytocin and vasopressin: implications for anxiety, depression, and social behaviors. Trends in Neurosciences 2012; 35:649-59.

https://doi.org/10.1016/j.tins.2012.08.004
29. Stein A, Arteche A, Lehtonen A et al. Interpretation of infant facial expression in the context of maternal postnatal depression. Infant Behav Dev 2010; 33:27327.

https://doi.org/10.1016/j.infbeh.2010.03.002

30. Seth S, Lewis AJ, Galbally M. Perinatal maternal depression and cortisol function in pregnancy and the postpartum period: a systematic literature review. BMC Pregnancy Childbirth 2016; 31;16:124. https://doi.org/10.1186/s12884-016-0915-y

31. D Rheim SK, Bjorvatn BR, Eberhard-Gran M. Insomnia and depressive symptoms in late pregnancy: a population-based study. Behav Sleep Med. 2012; 10:152-66.

https://doi.org/10.1080/15402002.2012.660588

32. Christesen HT, Falkenberg T, Lamont RF et al. The impact of vitamin $\mathrm{D}$ on pregnancy: a systematic review. Acta Obstet Gynecol Scand 2012; 91:1357-67. https://doi.org/10.1111/aogs.12000

33. O'Hara MW, Swain AM. Rates and risk of postpartum depression-a meta-analysis. Int Rev Psychiatry 1996; 8:37-54. https://doi.org/10.3109/09540269609037816

34. Warner R., Appleby L., Whitton A et al. Demographic and obstetric risk factors for postnatal psychiatric morbidity. Br J Psychiatry 1996; 168, 607-11. https://doi.org/10.1192/bjp.168.5.607

35. Murray D, Cox JL. Screening for depression during pregnancy with the Edinburgh depression scale (EDDS). J Reprod Infant Psychol 1990;8:99-107. https://doi.org/10.1080/02646839008403615

36. Odalovic M, Tadic I, Lakic D et al. Translation and factor analysis of structural models of Edinburgh Postnatal Depression Scale in Serbian pregnant and postpartum women - Web-based study. Women Birth 2015; 28(3), pp. e31-e35. https://doi.org/10.1016/j.wombi.2015.01.014

37. VanderKruik R., Barreix M, Chou D et al. The global prevalence of postpartum psychosis: a systematic review. BMC Psychiatry 2017;17, 272.

https://doi.org/10.1186/s12888-017-1427-7 
38. Kirpinar I, Coşkun I, Cayköylü A et al. First-case postpartum psychoses in Eastern Turkey: a clinical case and follow-up study. Acta Psychiatr Scand 1999; 100:199-204. https://doi.org/10.1111/j.1600-0447.1999.tb10846.x

39. Righetti-Veltema M, Conne-Perreard E, Bousquet A et al. Risk factors and predictive signs of postpartum depression. J Affect Disord 1998; 49:167-80. https://doi.org/10.1016/S0165-0327(97)00110-9

40. Vukovic O, Damjanovic A, Maric N et al. Perinatalna psihijatrija: smernice u klinickoj praksi. Engrami 2008; 30(3-4):47-52.

41. Brockington I. Diagnosis and management of postpartum disorders: a review. World Psychiatry 2004; 3:89-95.

42. Farr SL, Dietz PM, O'Hara MW et al. Postpartum anxiety and comorbid depression in a populationbased sample of women. J Womens Health (Larchmt) 2014; 23:120-8.

https://doi.org/10.1089/jwh.2013.4438

43. Austin MP, Hadzi-Pavlovic D, Priest SR et al. Depressive and anxiety disorders in the postpartum period: How prevalent are they and can we improve their detection? Arch Womens Ment Health 2010; 13:395-401.

https://doi.org/10.1007/s00737-010-0153-7

44. Hofberg K, Brockington I. Tokophobia: an unreasoning dread of childbirth. A series of 26 cases. $\mathrm{Br} \mathrm{J}$ Psychiatry 2000;176:83-5.

https://doi.org/10.1192/bjp.176.1.83

45. Cerulli C, Talbot NL, Tang W ET AL. Co-occurring intimate partner violence and mental health diagnoses in perinatal women. J Women's Health (Larchmt) 2011; 20, 1797-803. https://doi.org/10.1089/jwh.2010.2201

46. Buist A, Gotman N, Yonkers KA. Generalized anxiety disorder: course and risk factors in pregnancy. J Aff ect Disord 2011; 131: 277-83.

https://doi.org/10.1016/j.jad.2011.01.003

47. Russell EJ, Fawcett JM, Mazmanian D. Risk of obsessive-compulsive disorder in pregnant and postpartum women: a meta-analysis. J Clin Psychiatry 2013; 74: 377-85.

https://doi.org/10.4088//CP.12r07917

48. Wenzel A, Haugen EN, Jackson LC, et al. Anxiety symptoms and disorders at eight weeks postpartum. J Anxiety Disord 2005;19:295-311. https://doi.org/10.1016/j.janxdis.2004.04.001

49. Andersen LB, Melvaer LB, Videbech P et al. Risk factors for developing post-traumatic stress disorder following childbirth: a systematic review. Acta Obstet Gynecol Scand 2012; 91: 1261-72. https://doi.org/10.1111/j.1600-0412.2012.01476.x

50. Petik D, Czeizel B, Banhidy F et al. A study of the risk of mental retardation among children of pregnant women who have attempted suicide by means of a drug overdose. J Inj Violence Res 2012; 4:10-9. https://doi.org/10.5249/jivr.v4i1.85

51. Milovanović S, Milovanović D. Depresije -faktori rizika za njihov nastanak kod žena. Promocija zdravlja i prevencija bolesti žena, Farmaceutski fakultet, 2006.

52. Retnakaran R, Qi Y, Connelly PW et al. Glucose intolerance in pregnancy and postpartum risk of metabolic syndrome in young women. J Clin Endocrinol Metab 2010; 95:670-7.

https://doi.org/10.1210/jc.2009-1990

53. Stuebe AM, Willett WC, Xue F et al. Lactation and incidence of premenopausal breast cancer: a longitudinal study. Arch Intern Med 2009; 169:1364-671. https://doi.org/10.1001/archinternmed.2009.231

54. Murray L, Fiori-Cowley A, Hooper R et al. The impact of postnatal depression and associated adversity on early mother-infant interactions and later infant outcome. Child Dev 1996; 67: 2512-26. https://doi.org/10.2307/1131637

55. Stein A, Pearson RM, Goodman SH. Effects of perinatal mental disorders on the fetus and child. Lancet 2014; 384:1800-19. https://doi.org/10.1016/S0140-6736(14)61277-0 


\title{
Postporođajni psihijatrijski poremećaji: pregled istorije istraživanja, klasifikacija, epidemiološki podaci, etiološki faktori i kliničke prezentacije
}

\author{
Jelena Stojanov ${ }^{1}$, Miodrag Stanković2,3, Olivera Žikić2,3, Jovana Antonijević ${ }^{2}$ \\ 'Specijalna bolnica za psihijatrijske bolesti "Gornja Toponica", Niš, Srbija \\ ${ }^{2}$ Univerzitet u Nišu, Medicinski fakultet, Niš, Srbija \\ ${ }^{3}$ Centar za zaštitu mentalnog zdravlja, Klinički centar Niš, Nišs, Srbija
}

\section{SAŽETAK}

Postpartalni psihijatrijski poremećaji su mentalni poremećaji koji se javljaju nakon porođaja. Nelečena depresija $\mathbf{i}$ anksioznost $\mathbf{u}$ toku trudnoće, kao i stres $\mathrm{i}$ ranije depresivne epizode značajani su faktori rizika za nastanak postpartalnih psihijatrijskih poremećaja. Nakon porođaja najčešće se javljaju postpartalni bluz, postpartalna depresija i postpartalna psihoza, kao i postpartalni anksiozni poremećaji. Postporođajna depresija povećava verovatnoću nastanka psihijatrijskog morbiditeta $\mathbf{u}$ daljem životu. Prisustvo psihotične simptomatologije sa psihomotornom uznemirenošću i nepredvidivim ponašanjem značajni su faktori rizika za suicid ili infanticid. Istraživanja su pokazala da više od polovine žena sa depresijom u toku trudnoće ili postpartalnom depresijom ima u komorbiditetu i neki anksiozni poremećaj. Nakon porođaja povećava se mogućnost nastanka paničnog poremećaja i opsesivno-kompulzivnog poremećaja, a smanjuje se prevalencija generalizovanog anksioznog poremećaja. Pouzdan instrument za skrining spektra postpartalnih mentalnih poremećaja je Edinburgova postnatalna skala za depresiju - EPDS. Postpartalni psihijatrijski poremećaji narušavaju centralni psihološki proces, tj. razvoj emocionalnog odnosa između majke i deteta i negativno se odražavaju na ponašanje, kognitivni razvoj i fizičko zdravlje deteta.

Ključne reči: porođaj, postpartum, depresija, psihoza, anksiozni poremećaji 